UC-49

Reporting Date: August 1974

Issued: September 1974

\title{
Dose-Rate Effect on Life Shortening in Mice
}

by

J. F. Spalding

O. S. Johnson

R. F. Archuleta

G. L. Tietjen 
This report was prepared as an account of work sponsored by the United States Government. Neither the United States nor the United States Atomic Energy Commission, nor any of their employees, nor any of their contrac. tors, subcontractors, or their employees, makes any warranty, express or implied, or assumes any legal liability or responsibility for the accuracy, completeness or usefulness of any information, apparatus, product or process disclosed, or represents that its use would not infringe privately owned rights.

In the interest of prompt distribution, this IAMS report was not edited by the Technical Information staff.

Work supported by the Division of Biomedical and Environmental Research.

\author{
Printed in the United States of America. Available from \\ National Technical Information Service \\ U.S. Department of Commerce \\ 5285 Port Royal Road \\ Springfield, Virginia 22151 \\ Price: Printed Copy $\$ 4.00$ Microfiche $\$ 1.45$
}


This report was prepaced as an accusnt of wok spanseited by the United Siate; Government. Neither the Unied States nor the United States Atomic Energy Cummissiun, nor any of their empooyees, nor any of their contractors, subcontractors, or their employees, makes any warrants, express or implied, or assumes any legal liability of responsibility for the accuracy, com pleteness or usefulness of any information, apparatus, product or process Jisclosed, or represents that its we would not intringe privately owned rights.

DOSE-RATE EFFECT ON IIFE SHOTTENING IN MICE

by

J. F. Spalding, O. S. Johnson, R. F. Archuleta, and G. L. Tietjen

\section{ABSTRACT}

An adult population of strain RF female mice were conditioned with thirteen discrete doses of cobalt-60 gamm rays ranging from 457$3455 \mathrm{rad}$ given at a dose rate of $2.76 \mathrm{rad} / \mathrm{h}$. Median after-survival times of conditloned groups were compared with control nunconditioned groups to determine life-shortening effects of gama rays given at a relatively low dose rate. No 11near dependence of life shortening on dose was observed. The average life shortening for all cond $1+1$ on 1 ing doses used was 83 days $(0.04$ day/rad). The relatively small 11 feshortening effects observed were attributed to several factors, 1ncluding age at exposure and dose rate, and not to dose rate alone.

\section{INTRODUCTION}

Radlation-1nduced life shortening is recogalzed as one of the few consistently observed effects of persistent infury from whole-body exposure to lonizIng radiation, and the effect per ae does not appear to be age-, sex-, specles-, or strain-dependent. Although small but permanent decrements in body welght, (1) activity, (2) and resistance to cold stress (3) have been shown to be effects of persistent radiation infury, the major concern is the damaging effects that cause premature mortality, their nature, and extent to which they may depend on dose rate.

The speciflc nature of the chronic or long-term leston from exposure to lonizing radiacton is not well understood. A reduction of 11 fe span in rodents given a single acute dose or several doses in discrete fractions is generally accepiced as a chronic effect of whole-body exposure to lonizing radiation. This radiation-1nduced life shortening has been called "radiation aging." Simflarictes and differences between natural and radiation-induced aging have been reviewed and studied extensively. (4-12) Definitive studies on experimental animals and human populations exposed to lonizing radiation (13) have shown that radiation-induced life shortening cannot be described as an acceleration of normal aging in that it does not hasten the onset or progression of natural aging with all of the latter's manlfes tations.

Radiation-1nduced life shortening from acute radiation insults is reported to be a function of, and generally linear with, dose. $(4,8,10,14,15,16)$ The average life-shortening effect of acuse $x$ - or gama-ray exposures in the reviewed reports was $0.34 \mathrm{day} / \mathrm{rad}$. $(4,5,8,10,14,16)$ Dose fract1onation is reported to be less effective than single acute doses in refucing $11 \mathrm{fe}$ span, and as the interval between fractions is increased there is a tendency toward 1ncreasing the survival time. (17) Dose protraction has been estimated to be less effective than acutely dellvered lonizing radiation by a factor of approximately four. (18) Although some data are avallable on the possible amellorating effects of dose protraction on the persistent radiation lesion resulting in life shortening, $(2,17)$ this estimate is based primarily on continuous low-dose-rate exposureto-death data. Investigations designed to deterwine the 11fe-shortening effects of whole-body exposure at low dose rate are not evident in the literature. This Investigation was performed to provide the needed information in this area. 


\section{METHODS}

Nine hundred and forty-four virgin female $\mathrm{kF}$ strain mice were used. The mlce averaged 317 days of age, with a standard deviation of 27 days. Th1s age group was selected to simulate an aduit population that has attalned full growth ${ }^{(19)}$ and peak activity. (20) The animals were selected at random and were divided into thirteen groups. Each group was exposed to ${ }^{60}$ co gamma rays at $2.76 \mathrm{rad} / \mathrm{h}$ until a predetermined dose had been accumulated. The dose recelved by each group is shown in Table I. Earlier sose-rate Investigations using RF mice suggested that $\$ 455 \mathrm{rad}$ given at $2.76 \mathrm{rad} / \mathrm{h}$ would be the maxtmum cose from which survival might be expected. (21) I'ose rates were determined with a 2.5-r high-energy range victoreen chamber at the front, mid-point, and tack of the exposure cage, and the average of the three dose measurements was used. After exposure, the mice were housed five per cage on wood shavings In box-type, $12.7 \times 20.32 \times 30.48-\mathrm{cm}$, stainless$s$ teel cages. Fresh bedding and water were provided cn a weekly basis, and rodent food was given ad libition. The mise were observed dally to record deaths and to ensure proper animal care. Survival

TABLE I

:STRAIN RF VIRGIN FEMALE MICE 317 + DAYS OLD EXPOSED TO DISCRETE GAMMA-RAY DOSES AT $2.76 \mathrm{rad} / \mathrm{h}$

\begin{tabular}{|c|c|c|c|c|c|}
\hline \multirow[b]{2}{*}{$\begin{array}{l}\text { ?otal } \\
\text { ?ose } \\
\text { rad) }\end{array}$} & \multirow[b]{2}{*}{$\begin{array}{c}\text { Exposure } \\
\text { Time } \\
\text { (days) }\end{array}$} & \multicolumn{4}{|c|}{ Number of Mice } \\
\hline & & Exposed & $\begin{array}{l}\text { Completed } \\
\text { Exposure }\end{array}$ & $\begin{array}{l}\text { Survive } \\
\text { Post-E } \\
\text { (No.) }\end{array}$ & $\begin{array}{l}60 \text { Days } \\
\text { posure } \\
(\%) \\
\end{array}$ \\
\hline 457 & 7 & 75 & 74 & 72 & 96 \\
\hline 914 & 14 & 75 & 74 & 71 & 95 \\
\hline$\therefore 154$ & 18 & 78 & 78 & 75 & 96 \\
\hline$: 388$ & 21 & 75 & 74 & 69 & 92 \\
\hline$\therefore 564$ & 24 & 76 & 76 & 70 & 92 \\
\hline$: 841$ & 28 & 75 & 73 & 68 & 91 \\
\hline 2078 & 32 & 75 & 71 & 50 & 67 \\
\hline 2314 & 36 & 75 & 71 & 49 & 65 \\
\hline$: 503$ & 38 & 75 & 73 & 42 & 56 \\
\hline$: 783$ & 43 & 95 & 94 & 57 & 60 \\
\hline$: 008$ & 46 & 30 & 27 & 11 & 37 \\
\hline$: 455$ & 53 & 30 & 10 & 0 & 0 \\
\hline 0 & $28^{\circ}$ & 110 & 110 & 106 & 96 \\
\hline
\end{tabular}

${ }^{\bar{c}}$ Rounded to days and includes source down-time.

${ }^{b}$ Mean exposure time of 11 groups used. times for this investigation were deternined from the first day of axposure.

\section{RESULTS AND DISCUSSION}

Conditioning doses used, exposure t1mes, number of mice exposed, those completing exposure, and those surviving to 60 days after exposure are shown In Table $I$. Only mice that survived to 60 daye after termination of exposure were used in the comparative survival-time calculations. Mice that died within 60 days after belng removed from the exposure environment were assumed to have diod from infury other than that resulting in a long-term residual leston.

The number of 60-day survivors of each dose yroup is expressed as \% of the total numier exposed in Table $I$ and In Fig. 1. Most of the mice exposed to $1841 \mathrm{rad}$ or less survived through the 60-dicy postexposure period and were Included in the median after-survival (MAS) calculartions. As condictoning doses were increased above $1841 \mathrm{rad}$, the $\%$ of $60-$ day survival decreased. In F1gs. 2 and 3, the cumulative distribution of survival time (frot the begianing of exposure) is shown for the control group, the group with the lowest conditioning dose (457 rad), and the group with the highest condition1ng dose ( $3008 \mathrm{rad})$. For comparat tve purposes, a normal distribution with mean $(\bar{x})$ and standard

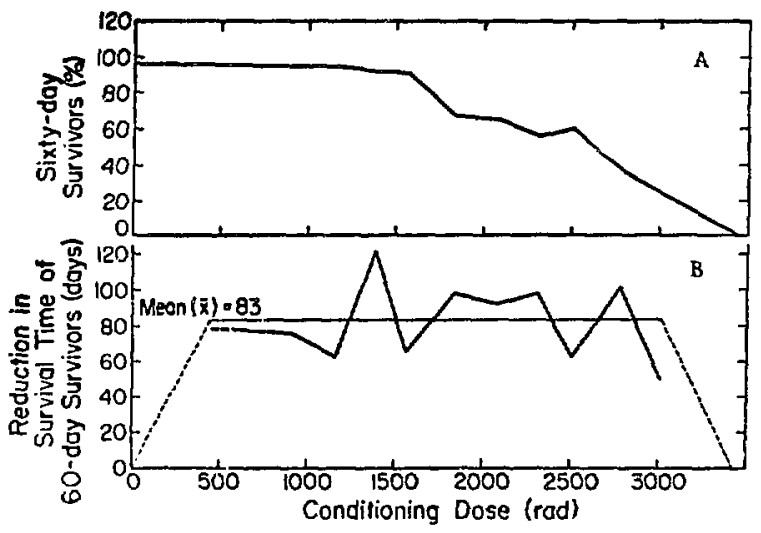

F1g. 1. (A) Survivors (at 60 days) of thirteen conditioning doses, expressed as $\%$ of the number of mice exposed. (B) keduction in surulval time vs conditioning dose of 60day survivors of thitteen conditioning doses. The 11 fe-shortening effects of doses between $0-457$ rad and between 3000$3500 \mathrm{rad}$ (from which there were no survivors) were not studied. These points are connected with dashed lines. 


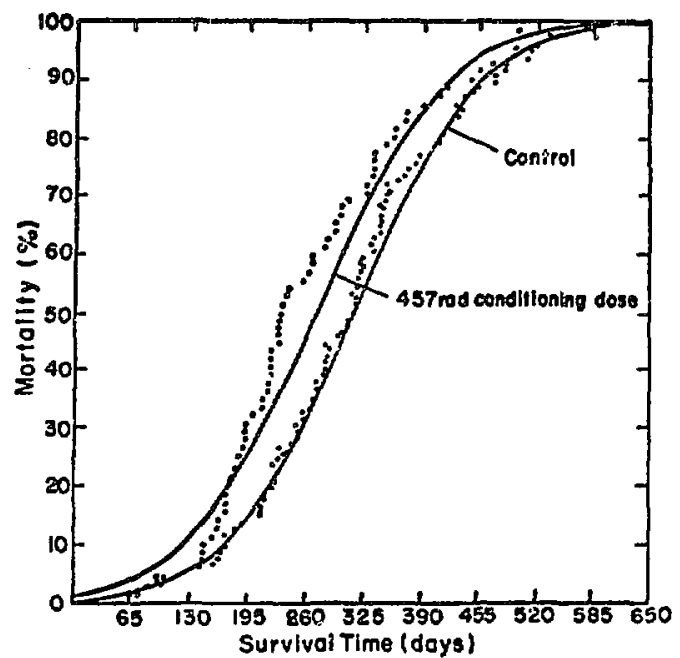

F1g. 2. Suryival time distributions of nonconditioned mice and mice conditioned with 457 rad of gamma rays.

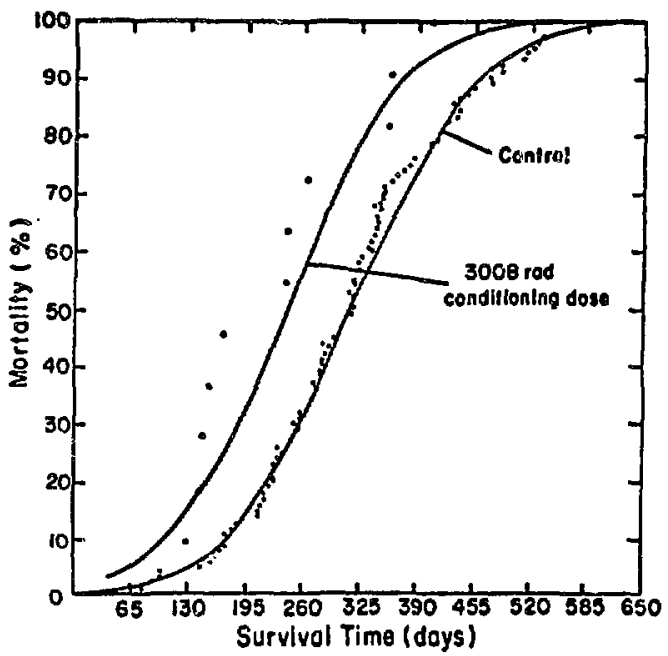

PIg. 3. Survival time distributions of noncond1tioned mice and mice conditloned with 3008 rad of gamma rays.

deviation (s) is plotted for each set of data as a solid line. While the control group appears to be normally distributed, the treated groups have a skewed distribution. As a consequence, the median seems to be more meaningful than the mean as an expression of the most typical survival time.

Table II gives, for each conditioning dose, the reduction in gurvival time (1.e., the difference be-tween the expected survival time and the observed median survival time). The expected survival tfme is the median survival time of the control group
TABLE II

RRDUCIION IN SURVIVAI, TIME ${ }^{a}$ OF MICE GIVEN GRADED DOSES OP GAMUL RAYS AT $2.76 \mathrm{rad} / \mathrm{h}$

\begin{tabular}{|c|c|c|c|}
\hline $\begin{array}{l}\text { Accurauluted } \\
\text { Dose (rad) }\end{array}$ & $\begin{array}{l}\text { Expecteil } \\
\text { Median } \\
\text { Survival } \\
\text { rfme } \\
\end{array}$ & $\begin{array}{c}\text { Observed } \\
\text { Median } \\
\text { Survival } \\
\text { Time } \\
\end{array}$ & $\begin{array}{l}\text { Rediction in } \\
\text { Survival Time } \\
\text { (days) } \\
\end{array}$ \\
\hline 0 & -- & 315 & $-m$ \\
\hline 457 & 315 & 236 & 79 \\
\hline 914 & 315 & 239 & 76 \\
\hline 1154 & 278 & 215 & 63 \\
\hline 1388 & 315 & 194 & 121 \\
\hline 1564 & 285 & 219 & 66 \\
\hline 1841 & 315 & 217 & 98 \\
\hline 2078 & 293 & 201 & 92 \\
\hline 2314 & 315 & 217 & 98 \\
\hline 2503 & 301 & 238 & 63 \\
\hline 2783 & 308 & 207 & 101 \\
\hline 3008 & 308 & 258 & 50 \\
\hline $3455^{\mathrm{c}}$ & $-\infty$ & -- & - \\
\hline
\end{tabular}

${ }^{\text {a }}$ Survivel time was calculated from the first day of exposure.

$b_{\text {The axpected median survival time varies because }}$ the first day of exposure was not the same for all grougs.

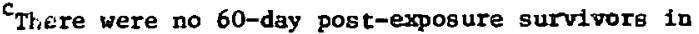
this group.

(because of normality, the median for the control group is quite close to the mean). Both observed and expected survival times are reckoned from the beginning of exposure, and both quantities are given in Table II. The lowest conditioning dose given (457 rad) caused a reduction in survival time of 79 days, whereas the largest conditioning dose with 60-day survivors ( $3008 \mathrm{rad}$ ) caused a reduct ton in survival time of 50 days. As conditioning doses were increased, there was no accompanying 1ncrease In iffe shortening. This relationship between life shortening and conditioning dose is also apparent in data reported by upton et al. (16)

Figure 1 shows the reduction in survival time vo conditioning dose. The slope of the reg-ession Ine (not shown) is not significantly different from zero; therefore, there is no linear dependence on dose, as has generally been reported in the literature. $(5-8,10,11,13,14,18)$ We conclude that 
any dose between 457 and $3008 \mathrm{rad}$ has about the same effect on survival time (1.e., there is an average lif a shortening of approxtmately 83 days for any dose in this range). This would indicate that, if one were to assume a linear relationship with dose between 0-457 rad, the effect on life shortenting would be on the order of $83 / 457=0.18 \mathrm{day} / \mathrm{rad}$, about half the $0.34 \mathrm{day} / \mathrm{rad}$ reported in earlier Invest 1gations. $(2,7,8,14,15,18,19)$ It may be that the saturation point of injury that hastens the onset of killing diseases 1 a reached earlier than this dose, but the question which also ralses itself at this point is the following: Is the effect of radiation dependent on the age at which it is recetved? If so, is the effect linear with age? The answer to the last question seems to be in the negative.

Radiation-induced life shorrening, as reported by several researchers, is plotted as a function of age at exposure In Fig. 4, with 600 days as the mean life span for the mouse. Most studies reported used relatively young mice. A straight line appears to be a reasonable fit on a semt-log graph. Thus, a nonlinear relationship between age at exposure and radiation-1nduced life shortening from the long-term lesion does appear to exist (Fig. 4). Mole ${ }^{(9)}$ has

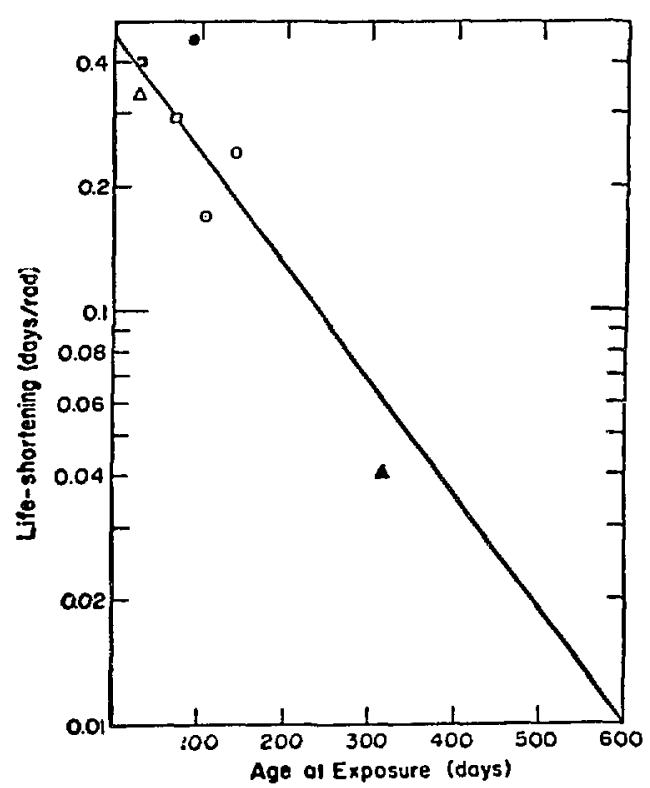

81g. 4. Life shortening (In days/rad vs age) of mice when exposed to conditioning doses: Storer (-৫) ; Lindop (- $\Delta-)$; Upton (-D-); Spalding (-0-); Silini (-0-); and estimate from current data (-\$-). reported that chronologicai aging and radiation are not additive and that iffe shortening is not a linear function of dose. Thus, the life-shortening effects of radiation exposure may be assumed to be influenced by both dose rate and age at exposure. The relatively small life shortening observed here is perhaps attributable to several factors, includIng age and dose rate. The cause of death of mice with different challenge doses was not determined. however, survival time distributions of nonconditioned and conditioned groups did not show a clustering effect. Survival-time distributions of the nonconditioned group are compared with those of the groups given the highest and lowest conditioning doses, as shown In Ffgs. 2 and 3. Although the survival curves of conditioned groups were shifted to the left of those for nonconditioned groups, the slopes of the curves vere simflar (1.e., the means: are different, but the viriances are not very difrerent). Radiation-Induced Iife-shortening Investigations, Including the dose rate and age factors required to provide definitive answers to the dose-rate and age questions such as how they may affect the incidence of neoplasms and other killing diseases, have not yet been done.

\section{RE FE RENCES}

(1) L. F. Niras and C. Sutton, Amer. J. Phys1o1, 171, 17 (1952).

(2) G. E. Stapletion and 3. H. Curtis, Manhattan Project report MDDC-696 (1946).

(3) T. T. Truj1110, J. F. Spaliling, and W. H. Langham, Radiation Res. 16, 144 (1962).

(4) P. Alexander and D. I. Connell, Radiation Res. 12, 38 (1960).

(5) P. Alexander and D. I. Connell, in Proceedings of a Symposium Held in London (27-30 March i962) under the Auspices of the United Nations Educat ional, Scientific and Culcural organization and the Internat Ional Atomic Energy Agency. K. J. C. Harrls, Ed. SAcademic Press, Inc., New York and London), PP. 277-283.

(6) R. E. Anderson, J, V. Scaletri, and J, L. Howarth, Exp. Gersntol. 7, 289 (1972).

(7) G. W. Casarstt, Adv. Gerontol, Res. 1, 109 (1964).

(8) P. J. Lindop and J. Rotblat, Nature 180, 645 (1961).

(9) R. H. Mole, in Proceedings of a Symposium Held In London (27-30 March 1963) under the Auspices 
of the United Nations Educational, Scientific and Cultural Organization and the International Atomic Energy Agency, R. J. C. Harris, Ed. (Academlc Press, Inc., New York and London, 1963), pp. 273-276.

(10) J. B. Storer, Radiation Res. 25, 435 (1965).

(11) A. C. Upton, M. A. Kastenbaum, and J. W. Conklin, in Proceedings of a Symposium Held in London (27-30 March 1962) under the Auspices of the United Nations Educational, Scientific and Cultural Organization and the Internat icinal Atomlc Energy Agency, R. J. C. Harris, Ed. (Academic Press, Inc., New York and London, 1963), Pp. 285-294.

(12) H. E. Walburg, G. E. Cosgrove, and A. C. Upten, in Proceedings of a Colloguium Held in Sermering, Austria, P. J. Lindop and G. A. Sacher, Eds. (Taylor and Francis, Ltd., London, 1966), PP. 361-365.

(13) R. E. Anderson, Amer. J. Med. 55, 643 (1973).

(14) P. J. Lindop and J. Rotblat, in Proceedings of a Symposium Held in London (27-30 March 1962) under the Auspices of the United Nat Ions Educational, Sclentiflc and Cultural Organization and the International Atonic Energy Agency. R. J, C, Harris, Ed. (Academic Press, Inc., New York and London, 1963), pp. 313-315.

(15) J. F. SFalding, O. S. Johnson, and P. C. McWililiams, Radiation Res. 32, 21 (1967).

(16) A. C. Upton, M. L. Randolph, and J. W. Conklin, Radiation Res. 32, 593 (1967).

(17) G. Silini and P. Metalli, in Proceedings of a Colloquium Held in Semering, Austria, P. J . Lindop and G. A. Sacher, Eds. (Taylor and Francis, Ltd., London, 1966), pp. 207-215.

(18) W. H. Langham, Ed., "Radiobiological Factors in Manned Space Flight" (National Academy of Sciences-National Research Council, Washington. D. C. , 1967), PP. 157-169.

(19) J. F. Spalding, M. R. Broolis, and G. I. Tietjen, Genetics 63, 897 (1969).

(20) J. F. Spalding, Proc. Soc. Exp. Biol. Med. 124, 833 (1967).

(21) J. F. spaiting, T. T. Trujillo, and P. McWillams, health Phys. 10, 709 (1964). 